IZA DP No. 10096

Industrialization in China

Loren Brandt

Debin $\mathrm{Ma}$

Thomas Rawski

July 2016 


\title{
Industrialization in China
}

\author{
Loren Brandt
}

University of Toronto

and IZA

Debin Ma

London School of Economics

Thomas Rawski

University of Pittsburgh

\section{Discussion Paper No. 10096 \\ July 2016}

IZA
P.O. Box 7240
53072 Bonn
Germany

Phone: +49-228-3894-0

Fax: +49-228-3894-180

E-mail: iza@iza.org

Any opinions expressed here are those of the author(s) and not those of IZA. Research published in this series may include views on policy, but the institute itself takes no institutional policy positions. The IZA research network is committed to the IZA Guiding Principles of Research Integrity.

The Institute for the Study of Labor (IZA) in Bonn is a local and virtual international research center and a place of communication between science, politics and business. IZA is an independent nonprofit organization supported by Deutsche Post Foundation. The center is associated with the University of Bonn and offers a stimulating research environment through its international network, workshops and conferences, data service, project support, research visits and doctoral program. IZA engages in (i) original and internationally competitive research in all fields of labor economics, (ii) development of policy concepts, and (iii) dissemination of research results and concepts to the interested public.

IZA Discussion Papers often represent preliminary work and are circulated to encourage discussion. Citation of such a paper should account for its provisional character. A revised version may be available directly from the author. 


\section{ABSTRACT}

\section{Industrialization in China*}

We see industrialization in China the last 150 years as an ongoing process through which firms acquired and deepened manufacturing capabilities. Two factors have been consistently important to this process: openness to the international economy and domestic market liberalization. Openness and market liberalization are usually complementary: One without the other can seriously limit benefits. For a latecomer like China, modern industry initially finds its most success in more labor-intensive products that require only modest capabilities. Gradual upgrading entails the shift into more skilled-labor and capital-intensive products and processes. China's experience shows that government can both support and obstruct this process. Our review of long-term data shows that i) China's industrial growth rate has consistently exceeded that of Japan, India and Russia/USSR not just in recent decades but throughout most of the $20^{\text {th }}$ century; ii) China's shift from textiles and other light industry toward defense-related industries began before rather than after 1949, as did the geographic spread of industry beyond the initial centers in the Lower Yangzi and the Northeast (formerly Manchuria) regions; iii) the state sector has consistently been a brake on industrial upgrading, highlighting the significance of current reform initiatives in determining China's future industrial path.

JEL Classification: $\mathrm{O}, \mathrm{N}$

Keywords: China, industrial development, structural change

Corresponding author:

Loren Brandt

Department of Economics

University of Toronto

150 St. George Street

Toronto, Ontario M5S 3G7

Canada

E-mail: brandt@chass.utoronto.ca

\footnotetext{
* The authors have benefited from Guenther Lomas' dedicated research assistance, from data supplied by Bishnupriya Gupta, James Kung, Steven Nafzigar, and Li Nan, and from the comments and advice of Daniel Berkowitz, Kyoji Fukao, Hiro Good, Kevin O'Rourke, Dwight Perkins, Evelyn Rawski, Yingjun Su, Jeffrey Williamson, Haihui Zhang, Xiaodong Zhu and Xiuying Zou. The usual disclaimer applies.
} 


\section{Introduction}

China's recent economic boom, although widely viewed as a contemporary phenomenon, is the outcome of long-term processes with deep historical roots. Here, we apply this perspective to analyse the trajectory that has transformed China from hesitant $19^{\text {th }}$-century experimentation into the world's largest manufacturer.

Table 1 summarizes our central quantitative results. The unusual speed of China's post1978 industrial growth is well known. Much less appreciated is that rapid industrial growth extends back at least to 1912 . Over a period spanning nearly a century, Chinese manufacturing has grown at annual rate of more than 9 per cent. Table 2 provides further comparative perspective.

China's experience demonstrates however that industrialization is not simply the multiplication of commodity flows in and out of furnaces, mills and machine shops. How growth occurs, the relative roles of the intensive and extensive margins, and more generally, the underlying microeconomic processes are key to maintaining long-run momentum, and to industrialization's economy-wide impact. Similar growth rates of manufacturing can conceal wide differences in the progress of industrialization, which we see as a fundamentally microeconomic process that enables firms and individuals to accumulate and deepen the technical, operational, managerial and commercial skills that enable them to compete in ever more demanding markets, releasing multiple benefit streams that then reverberate throughout the economy. China's planned economy period, covering roughly 1952-1978, recorded impressive rates of output growth, but did so under a policy and institutional environment that ultimately restricted the pace of change to a fraction of its potential, and carried high costs for the rest of the economy. Institutional and policy constraints similarly obstructed early industrialization efforts of the late $19^{\text {th }}$ century.

Two factors have consistently served as important drivers of Chinese industry's global rise: openness to the international economy and domestic market liberalization.

Openness is important for the access it allows to new technology and know-how through foreign direct investment (FDI), imports of intermediates and capital equipment, and the movement of people and ideas. For a huge continental economy like China's in which the domestic market has typically absorbed upwards of eighty-five per cent of industrial output (Table 3), openness defined solely in terms of access to overseas markets cannot claim paramount importance. Domestic market liberalization is the crucial source of new opportunities and competitive pressure on incumbents and entrants to upgrade through product improvement and cost reductions, thus channelling resources to firms and sectors with high returns.

For latecomers like China, modern industry initially involves labour-intensive production requiring only modest capabilities. Over time, upgrading propels a shift into more skilled-labour and capital -intensive products and processes. Our review of a century 
and a half of Chinese industrialization shows that upgrading occurred most rapidly when the policy environment provided ample opportunity for the complementary interaction between openness and market liberalization, and helped roll back the institutional barriers that have often hindered the deepening of industrial capabilities.

While the past 150 years have seen wide variations in both international openness and domestic liberalization, we can identify several major dimensions of industrial development that have operated continuously throughout the period under review, albeit at different levels of intensity.

First, manufacturing activity and industrial capabilities have gradually spread across China's vast landscape. Factory production initially clustered along China's southeastern coast, particularly in the Lower Yangzi region surrounding Shanghai, and subsequently in Manchuria. The war years (1937-1949) brought a surprisingly large expansion of industry in China's interior (Table 4). The planned economy era (1949-1978) modestly extended regional dispersion, most notably through the Third Front policies, as the state limited investment in previously dominant regions, which were seen as both militarily vulnerable and ideologically suspect, and developed industrial capacity inland. Although the post-1978 reform era allowed coastal regions to once again leverage their favourable location and superior resources of education, skill and market experience to regain their share of national production, nationwide infrastructure expansion along with steeply rising land and labour costs in coastal cities encouraged growth in the central and western regions.

Second, industrial product mix has expanded. Even without tariff protection, import substitution is visible from the late $19^{\text {th }}$ century, particularly in cotton textiles. Import replacement on a more modest scale appeared elsewhere, particularly in segments of machine building, where the 1930s saw Chinese firms producing small quantities of textile machinery, machine tools, transportation equipment, and light armaments. Socialist planning grafted whole sectors, including trucks, petroleum refining, telecom equipment, nuclear fuel and many others onto the inherited industrial base. Although reform allowed market forces to exert growing influence over China's industrial product mix, government agencies continue to promote import replacement in computers, chemicals, machine tools and other sectors that officials perceived as either essential building blocks for future development or as militarily important.

Third, domestic upgrading has reduced the gap separating leading Chinese producers from global standards. Even without strong official support, progress in this direction became visible during the 1920s and 1930s, especially in cotton textiles. Chinese yarn producers moved beyond the coarsest grades of cotton yarn, improved labour and machine productivity, and absorbed management practices from British and Japanese rivals, while new academies offered training programs in textile technology and civic organizations hired foreign technicians to facilitate the production and dissemination of Japanese-style equipment for handcraft weaving. 
Beginning in the 1950s, the government of the People's Republic (PRC), tapping its new fiscal strength and the availability of technical support from its Soviet and East European allies, initiated what was then the largest technology transfer in human history. While the characteristic Soviet focus on production volume limited quality improvements and innovation, the accumulation of knowledge, resources and experience under the planned economy created upgrading potential that could be captured once post-1978 reforms encouraged the revival of incentives and allowed greater flexibility in the allocation of resources.

Upgrading accelerated after 1978, spurred by the growing presence of foreign-invested firms, the unfamiliar demands of new export markets in rich countries, and the opportunities arising from growing access to international supply chains and crossnational information flows. The result was a growing dispersion of capabilities, as successful firms gradually moved toward global frontiers, leaving weaker units floundering in often overcrowded domestic markets for inferior goods.

Fourth, despite wrenching political discontinuity, successive advances build on prior developments. Early industrial efforts often involved individuals with modern education and/or overseas experience - both linked to international openness. Personnel from the pre-1949 National Resources Commission and from Japanese-controlled development efforts in Manchuria contributed disproportionately to early socialist planning. Even though the planned economy diverted investment away from Shanghai, China's pre-war industrial leader, the great metropolis figured centrally in the new system as a source of revenue from the profits of its consumer manufactures, and as a source of expert personnel -especially in textiles. Interior development was seeded with whole factory communities transported from Shanghai and other coastal locations. Reform-era development drew in similar fashion on the experience and skills accumulated within the plan-era state enterprise system, which became a source of expertise for both the township-village (TVE) firms and emerging private-sector manufacturers (Li et al., 2012; Dinh et al., 2013).

Finally, the Chinese diaspora has acted as a substantial source of financial and human capital in all periods except for the planned economy era. Its prominence reflects the unusual entrepreneurial propensity of ordinary Chinese, which survived several decades of intense anti-business propaganda under Mao and emerged as a key element in the astonishing reform-era expansion of private business (Table 5). Large numbers of microentrepreneurs in Wenzhou and other localities helped to propel Chinese exports to dominant positions in global market segments - an unusual, perhaps unique phenomenon in global economic history.

Following a brief quantitative overview, we review development during three periods: the decades prior to the establishment of the PRC in 1949; China's era of socialist planning, which extends from the early 1950s to the late 1970s; and the succeeding period of economic reform, which begins shortly after the death of Mao Zedong (1976) and continues today. 


\section{Quantitative Overview}

Table 1 provides a comparative perspective on China's long-term industrial growth ending with 2008, the most recent census year for which firm-level data are publically available. ${ }^{1}$ With the sole exception of Japan during its heyday of accelerated growth, the pace of Chinese industrial expansion exceeded that of India, Japan and USSR/Russia during every sub-period for which meaningful comparison is feasible. Table 2 uses information on physical commodity output and industrial employment to provide crude comparisons of the scale of industrial activity in China, India, Japan and USSR/Russia during the century beginning in 1912 . These data portray early $20^{\text {th }}$-century China as an industrial pygmy, trailing India's production of cotton textiles and lagging far behind Japanese and Russian/Soviet production of electricity, steel and cement.

Data for 1933 and 1952 suggest rough parity between Chinese and Indian industrial activity. An international comparison of industrial energy use during 1936/37 provides a clear ranking: industries in China (including Manchuria) and British India each absorb the equivalent of 19 billion kWh of electricity per year, one-third the figure for Japan and one-sixth the total for the USSR (U.S. Department of State, 1949, pp. 96-97).

Manufacturing contributed 2.1 and 3.2 per cent of China's 1933 and 1952 GDP respectively (in 1933 prices); adding mining and utilities (but not handicrafts) raises the 1933 figure to 3.3 per cent (Liu and Yeh, 1965, p. 66). PRC compilations show a rapid increase in the GDP share of industry (including mining and utilities), which rises to 44.1, 41.0 and 48.6 per cent in 1978, 1995 and 2008 (Compendium, 2009, p.10).

Beginning in the mid-1950s, Chinese industry rapidly outpaced India's. China's scale of industrial operations overtook Japan's shortly before the turn of the century, and surpasses the USSR's peak levels soon after 2000.

\footnotetext{
${ }^{1}$ Unless otherwise noted, industrial growth rates are based on measures of gross output value (GVIO) rather than the value-added data used in conventional national income accounts. Following Soviet practice, GVIO has served as the standard metric for industrial output since 1949, whereas value-added is a recent addition to the Chinese statistical repertoire. PRC materials use the term "industry" to describe aggregates that include mining and utilities as well as manufacturing. We follow this convention: unless otherwise indicated, measures of GVIO and "industrial" production or employment include mining and utilities as well as manufacturing.
} 


\section{China's Pre-1949 Industrial Development}

3.1. Overview. We observe three phases of pre-1949 industrialization: slow development during the late $19^{\text {th }}$ century, including both officially-inspired and private commercial efforts, followed by a more dynamic, market-driven expansion triggered by the Treaty of Shimonoseki (1895), which eroded barriers to private factory ventures. Subsequently, Japanese military pressure culminating in the Sino-Japanese War (193745) and civil war (1945-1949) prompted growing state intervention. Over this period, government became the chief driver of industrial development, leading to a rise in the share of military-linked activity and an enlarged output share for interior regions.

The Treaty of Nanking, which ended the Opium War (1839-1842), obliged China to open five ports to unlimited trade, to limit tariffs to five per cent, and to exempt foreigners from Chinese law. Later agreements multiplied the number of "treaty ports," and awarded similar privileges to citizens of multiple European nations as well as the United States and Japan. The resulting regime of obligatory free trade lasted until China regained tariff autonomy in 1929.

Falling international transport and communication costs complemented by rising trade volumes gradually aligned China's price structure, which displayed substantial domestic integration before the Opium War (Wang, 1992), with global values (Brandt, 1985). The resulting changes included price reductions (cotton yarn, ferrous metals) and increases (cotton, silk, tea), as well as the appearance of new products (machinery, kerosene, matches) that impacted prices of domestic substitutes and complements for traded goods.

3.2. Slow development during the first half-century of openness. Openness elicited a strong response in some segments of China's economy, e.g., Fujian's tea growers (Gardella, 1994, pp. 74ff). Development of manufacturing, however, was slow, both for semi-official initiatives directed by prominent regional leaders and for private ventures, some involving foreign entrepreneurs, that focused on processing of silk and other farm products. While the Jiangnan Arsenal impressed Japanese visitors, and China's Hanyeping complex initiated modern ferrous metallurgy ahead of Japan's Yahata works, the officially-linked initiatives, most focused on defence-related production, delivered limited results and produced virtually no spillovers for the private sector.

An earlier literature mistakenly linked this slow growth to the supposed inability of modern factory goods to compete with the products of China's traditional sector (Murphey, 1977; Huang, 1985). In reality, modern technologies enabled factory products to outcompete many traditional products in price and quality. Given Japan's 
faster industrial advance under similar trade and treaty arrangements, attributing limited manufacturing growth to Western imperialism is equally unpersuasive (Esherick, 1972; Moulder, 1977).

Institutional and ideological constraints that drained potential profits from embryonic industrial ventures posed a key obstacle to modern industry. Shannon Brown (1978, $1979 a, b)$ and others demonstrate how these difficulties undermined initiatives in soybean and silk processing. Entrenched local interest groups, possibly strengthened under the decentralization that accompanied the Taiping Rebellion (Brandt, Ma and Rawski, 2014) thwarted potential competition by blocking newcomers' access to materials (soybeans, cocoons), storage facilities and transport.

3.3. Accelerated growth from 1896 to 1937. In addition to opening the growing roster of treaty ports to foreign-owned manufacturing activity, stunning military defeat at the hands of Japan, a small and lightly regarded neighbour, prompted a sweeping reconsideration of traditional attitudes and structures. Rapid retreat of formal, and, perhaps more important, informal restrictions and prejudices became the order of the day as even conservative leaders endorsed sweeping reform. A new company law introduced limited liability; the traditional examination system gave way to a new drive toward modern education; Confucian-educated gentry turned to constitutionalism, parliamentary democracy and chambers of commerce as possible avenues to reverse China's decline.

This ferment facilitated a rapid acceleration of industrial enterprise formation. Table 6 shows the number of newly established modern Chinese private factories more than doubling between the 1880s and 1890s from 42 to 99 , before increasing to 437 during the first decade of the $20^{\text {th }}$ century. This wave of entry, complemented by growing FDI (Remer, 1933; Hou, 1965) initiated several decades of rapid industrial growth that persisted through periods of disunity, war and depression. Halting only with the outbreak of full-scale war with Japan in 1937, pre-war industrial growth outstripped that in Japan as well as India and Russia/USSR (Table 1). Work by Chinese scholars finds similarly high growth for Shanghai - the centre of pre-war manufacturing - between 1895 and 1912 (Ma, 2008).

Rapid growth from a minuscule base could not transform China into an industrial nation. At its pre-war 1936 peak, factory output accounted for only 3.1 per cent of GDP - far below the comparable Japanese figure of 25.1 per cent. Even with a substantial 
downward adjustment to the Liu-Yeh estimates of 1933 production, ${ }^{2}$ handicrafts contributed nearly half of industry gross output (and value added) in 1933, comparable to Japanese circumstances during 1900-1910 (Ohkawa and Shinohara, 1979, p. 37).

\subsection{Key features of early $20^{\text {th }}$-century industrialization.}

Labour-intensive production of consumer goods dominated China's early industrial landscape. Textiles, garments and food processing accounted for two-thirds of 1933 industrial output with or without the inclusion of handicrafts (Table 7).

Industrial activity was regionally concentrated. Nearly two-thirds of 1933 industrial production was located in the southeast coastal provinces (Table 4), with half more narrowly clustered in Shanghai and the adjacent Jiangsu province. A further 10 per cent was located in China's northeast (Manchurian) region, largely tied to Japanese investments. Data on newly established private factories prior to 1911 (Table 6) show a similar pattern of regional clustering.

Extreme geographic concentration resulted in large variations in industry's GDP share. For Shanghai and the adjacent Lower Yangzi region, an area with a population of 60 million, the GDP share of modern industry during the early 1930s may have reached 15 per cent, three times the national total and comparable to the role of industry in Japan by the late 1920 s. $^{3}$ Vast regions, especially in the west, experienced very limited development of modern industry prior to 1937.

Domestic entrepreneurs succeeded in rapidly overcoming their initial disadvantages inferior technical knowledge, poorer financing, and treaty provisions exempting foreign firms from many Chinese taxes. Table 8, which decomposes 1933 factory activity in China proper, ${ }^{4}$ puts the share of Chinese-owned firms in output and employment at 78 and 83 per cent respectively. ${ }^{5}$

\footnotetext{
${ }^{2}$ Liu and Yeh assign all non-factory production for food processing and textiles to the handicraft segment of China's 1933 industrial sector. Their estimate of "industrial” output thus includes non-commercial household production for self-consumption. Our attempt to remove non-commercial handicrafts from the industrial total focuses on the largest segments, textiles and food processing. We assume that commercial handicraft textile production in 1933 amounted to 90 per cent of factory textile output and that commercial handicraft food processing activity amounted to 100 per cent of factory output in that sector, with output measured by gross value in both sectors.

${ }^{3}$ Factories account for 15.8 per cent of Japan's 1929 GDP; calculated from Ohkawa and Shinohara (1979, p. 279), Ohkawa et al. (1974, p. 205) and Nakamura (1983, p. 80).

${ }^{4}$ Table 5 excludes Manchuria. Applying the 1931 share of Japanese-owned firms in Manchurian factory production (41.2 percent - see Mantetsu keizai chōsakai 1933, pp. 568-569) to Manchuria's 1933 factory
} 
Even though 90 per cent of 1933 factory production was sold domestically (Table 3), global market forces powerfully affected Chinese manufacturing throughout the prewar period. New domestic producers usually faced the task of wresting market share from foreign manufactures who attracted domestic buyers by offering alternatives for traditional products (manufactured yarn substituting for handicraft, cigarettes replacing pipe tobacco, kerosene being used for lighting rather than vegetable oil) and "new" goods (matches, steam engines). As a result, China's pre-war factory output closely paralleled the economy's comparative advantage.

Cotton textiles, pre-war China's leading industry, illustrate this tight link between global markets and pre-war factory development. Imports of manufactured yarn and cloth established market niches that were subsequently captured by local producers. Imports of yarn declined steeply after peaking in 1903 and again in 1914, and China emerged as a net exporter of cotton yarn beginning in 1927. Fabric imports peaked in 1913; by 1932-1936, their share in domestic consumption had dropped from over 25 per cent during 1910-1910 to only 8 per cent (Hsiao, 1974, pp. 38-39, 86; Kraus, 1980, pp. 116, J3; Feuerwerker, 1970; Brandt, 1989).

International influence permeated the development process. Chinese textile entrepreneurs hired foreign-trained technical staff, purchased imported equipment with advice from Shanghai-based foreign specialists, dispatched their sons to study abroad, and borrowed from foreign banks.

Competition among imports and domestic goods from foreign- and Chinese-owned factories spawned market segmentation, with Chinese firms initially serving the lower price-quality segments of contested product markets (Sutton, 2012). Chinese textile entrepreneurs initially produced yarn rather than fabric, and concentrated on low-count varieties, leaving the finer grades to foreign rivals (Hou, 1965, p. 153).

Market evolution and competitive pressure pushed firms to upgrade. During the 1920s, access to Japanese machinery and shifts in local demand encouraged spinning firms to shift their focus from "coarse low count yarn to. . . fine, high-quality, high-count" varieties (Köll, 2003, p. 265). Forcing out independent shop bosses and installing

output (Liu and Yeh 1965, pp. 427-428) reduces the share of Chinese-owned firms in nationwide factory output for 1933 to 69.6 per cent.

${ }^{5}$ For earlier decades, scattered data suggest wide variation in the share of foreign firms. We do not have data for all of industry for earlier years, but for textiles, Feuerwerker (1970) suggests long-term stability in the proportion of foreign ownership. Data assembled by Yan Zhongping show foreign dominance in pig iron, Chinese dominance in matches, and fluctuating shares in cigarettes and cement (Yan, 1955, pp. 127, 130). 
technically trained managers enabled some firms to secure steep productivity increases (Cochran, 2000, pp. 191ff; Zeitz, 2013). Chinese yarn producers matched the rising productivity of China-based Japanese firms and outperformed British-owned rivals during 1924-1936; in factory weaving, incomplete data show Chinese firms raising output per loom from 59 to 84 per cent of the levels recorded by Japanese-owned industry leaders (Zeitz, 2013, p. 125; Chao, 1977, p. 313).

Matches present a similar picture, with imports giving way to domestic production first by foreign and then by Chinese-owned firms. Liu Hongsheng, China's "match king," built his business in small cities ignored by foreign rivals, where customers put a premium on price over quality, and only later challenged the Japanese and Swedes in the Shanghai market, China's largest (Cochran, 1992, p. 61). Liu's strategy foreshadows the recent success of PRC start-ups in telecom equipment (Huawei) and construction machinery (Sany, Zoomlion, Liugong) that used capabilities accumulated through selling lower quality goods to less demanding markets to break into high-end global markets initially dominated by prominent multinationals like Caterpillar and Ericsson (Brandt and Thun, 2010).

\subsection{Impact on handicrafts.}

Estimating the scale and growth of handicrafts is difficult, but several propositions are clear.

Enforced free trade and factory expansion disrupted some craft sectors while giving new life to others. The overall effect was probably beneficial: exports of selected handicrafts grew at an average rate of 2.6 per cent per annum during 1875-1928, while combined exports of 67 handicrafts rose by an average of 1.1 per cent annually during 1912-1931 (Hou, 1965, p. 171).

Cotton textiles illustrate this mixed outcome. Handicraft spinning, squeezed by the dual blows of falling prices for factory yarn and rising cotton prices, suffered a steep decline (Feuerwerker, 1970). But the same low prices of factory yarn strengthened handicraft weaving, which thrived by combining factory and homespun yarns (Reynolds, 1974). Grove (2006) describes the critical role of Japanese advice and Japanese intermediate technology (wooden handlooms with iron gears) in expanding small-scale cloth production in north China.

Despite rapid factory growth, handicrafts persisted as an important component of industrial output as late as 1955, when they accounted for nearly 20 per cent of overall industrial production (Chen, 1967, p. 210). 


\subsection{Wartime developments}

Japan's 1931 takeover of China's northeast region, followed by a brief but intense attack on Shanghai in early 1932, focused attention on the need to prepare for war with Japan. The response included the establishment of official planning bodies, efforts to develop a network of state enterprises in defence-related industries, and monetary and banking reforms aimed at strengthening official control over money and credit. With the Japanese-led breakaway state of Manshūkoku adopting its own planned economy regimen, the approach of war initiated a nationwide shift from private to public enterprise and from market to government allocation that presaged the socialist system of the 1950s.

Once full-scale combat began in 1937, the combined effects of physical destruction, disruption of commercial and transport networks, fiscal difficulties arising from the westward retreat of China's national government, and hyperinflation undermined private manufacturing and limited the implementation of industrialization plans, especially for Chiang Kai-shek's Nationalist government. Consumer manufacturing centred on Shanghai suffered catastrophic reductions in capacity utilization: operating rates in flour milling fell by nearly 90 per cent between 1936 and 1945; in textiles, the decline was even steeper (Minami and Makino, 2014, annex table 4.D).

Official industrialization efforts, however, moved forward despite the travails of war. Indeed, rapid manufacturing growth immediately following the cessation of civil war in 1949 reflects substantial wartime increases in manufacturing capacity - expansion that pushed 1952 output to double the 1933 level and 65 per cent above the 1936 figure. Wartime investments also altered China's industrial structure, raising the share of producer goods from 25 to 42 per cent of manufacturing output, increasing the share of central, southwest and northwestern regions from 8.8 to 21 per cent, and sharply reducing the Herfindahl index for provincial industrial output from 0.25 to 0.09 between 1933 and 1952 (Table 4).

\subsection{Pre-1949 outcomes}

A century after British arms imposed a regimen of free trade, China in 1949 remained a primarily agricultural economy. Although industry grew rapidly during the early decades of the $20^{\text {th }}$ century, the share of manufacturing in overall output remained small. Even so, China recorded substantial progress along the path to industrialization. Following several decades of slow expansion, the shock of military defeat and the 1895 treaty provisions allowing foreign-owned factories in China's treaty ports unleashed a wave of reform. The ensuing acceleration of entry and growth provided China with a modest 
array of manufacturing industries, some of which - notably cotton textiles - achieved global visibility, that employed over one million workers in 1933 (Liu and Yeh, 1965, p. 428).

China's leading industrial regions, the Shanghai area and the northeast, reflected divergent sources of growth. In the Lower Yangzi region centred on Shanghai, private business was the main driver of pre-war industrial growth. Beginning around 1900, rapid expansion of consumer goods manufacturing powered an economy-wide transformation that paralleled Japan's earlier path. Expanding production of cotton goods, foodstuffs, matches and other consumer goods promoted backward linkage into engineering and chemicals, stimulated the development of commodity and financial exchanges, and prompted banks to extend financing to manufacturing and even agriculture (Rawski, 1980, 1989; Ma, 2008). Prior to 1931, government involvement was mostly indirect; support of modern banks, "the sector . . . that benefited most from its dealings with the government," was particularly significant (Kirby, 1984, p. 80). This changed after 1931 as the threat, and then the reality of war with Japan pushed the Chinese state to assert growing control over industries and markets previously influenced mainly by private activity and to inject itself directly into the allocation and operation of industrial resources.

In Manchuria, by contrast, government direction was evident throughout, with much factory investment coming from Japanese-controlled companies whose actions responded to Tokyo's economic priorities. Reflecting this circumstance, chemicals, machinery and, from 1936, metals - the central components of detailed official plans that extended into the 1950s - stand out as the largest contributors to factory valueadded (Chao, 1982, p. 83).

These developments occurred in an open economy, with free trade (from 1842), substantial price integration with global markets (from the 1880s), minimal restriction of FDI (from 1895), rapid expansion of new forms of education and overseas study, and considerable return migration by Overseas Chinese. Extensive openness magnified both the disruption (e.g. to handicraft spinning) and the opportunities resulting from the growth of international links.

Gradual emergence of growth-promoting institutions contributed to China's pre-war industrial growth. Private actors banded together to promote common interests. Köll (2003, p. 76) describes the spread of technical schools offering courses in textile engineering, the proliferation of technical journals and the emergence of an engineering profession, all foreshadowing developments that were vastly accelerated under state 
auspices after 1949. Local chambers of commerce facilitated the dissemination of knowhow and provided "voice" for newly emerging entrepreneurs (Chan, 1977).

State action, initially focused on sponsorship of semi-official enterprises during the late $19^{\text {th }}$ century, subsequently emphasized indirect actions that smoothed the path of private ventures: passing a corporation law, identifying and disseminating commercially promising technologies, and pursuing tariff autonomy.

As a result, China's pre-war economy displayed many features of a market system. Prices were flexible and generally market-determined. There were few man-made obstacles to domestic or international mobility of goods, people, information and ideas. Formal and informal entry barriers declined over time. Low revenue and, after 1911, weak central control restricted the state's ability to regulate and intervene.

This began to change soon after the Guomindang established the Nanjing government in 1927. Although restricted by weak finances and limited territorial control, the new administration set out to follow Japan and other rising powers by systematically deploying the levers of state power to build a modern industrial economy. Japan's assault on China's territorial integrity, which signalled a growing likelihood of all-out war, hastened the Guomindang's shift from supporting a largely private economy toward an emerging vision of a planned economy in which official direction of investment and state-owned enterprises (SOEs) would occupy leading roles.

The outbreak of war in 1937 led to "an enormous expansion of Nationalist China's economic bureaucracy," nationalization of many existing industrial operations, and planned production and distribution of essential war materials (Kirby, 1990, pp. 127128). By 1944, public-sector firms accounted for more than half of total industrial output and an even higher share of heavy industry (Bian, 2002, p. 85).

While the defeat of Japan brought a renewal of China's long-smouldering civil strife, the Guomindang and Communists shared a common vision of an industrial sector oriented toward military strength, directed by government technocrats, and dominated by staterun firms. When Communist forces routed their Guomindang rivals, "the large majority of Nationalist industrial planning personnel," including the "entire senior leadership" of the National Resources Council, the KMT's lead agency for economic planning, "remained on the mainland," imparting a strong element of continuity to the establishment of Soviet-aided socialist planning by the incoming PRC government (Kirby, 1990, p. 134). 


\section{Chinese Industry under Socialist Planning, 1949-1978}

The Chinese economy recovered quickly with the end of hostilities and the establishment of the PRC in 1949. By the mid-1950s, China succeeded in further institutionalizing and extending the system inherited from the preceding wartime era. In industry, two features were especially prominent: state ownership and the substitution of a planning system for markets.

Industry under socialism is as much a story of continuity as it is of change. State ownership had come to the fore during the 1940s. Nationalization of remaining private firms in the early 1950s and the concentration of new investment in the state sector simply reinforced this dominance. Between 1957 and 1978, the state sector consistently delivered over 80 per cent of GVIO, with the remainder coming from a large number of small urban collective firms and, beginning in the late 1950s, from an even larger number of rural collective enterprises.

Through an enlarged and integrated version of separate planning bureaucracies inherited from the former Guomindang and Manshūkoku governments, China moved to fully replace markets with administrative resource allocation. Decisions about output, input use and investment were now all in the hands of the planners.

Although China's plan system resembled its Soviet counterpart, there were important differences. The number of commodities for which planners constructed nationwide allocations was smaller than in the USSR. China's system was more decentralized, with substantial resources under the control of provincial and sub-provincial governments (Wong, 1985). This decentralization reflected a succession of initiatives that began during the mid-1950s and continued through the next two decades. Maskin, Qian and $\mathrm{Xu}(2000)$ argue that this feature of the pre-1978 economy had important consequences for the system's reform-era trajectory.

A central objective of the new system was to mobilize resources that planners could direct toward strategic objectives. Control over prices was critical: by setting prices of final goods high relative to those for inputs, including wages, planners could concentrate profits in the hands of SOEs. Low profit retention rates-firms were required to remit 
more than $95 \%$ of their profits-provided a revenue stream for the state that accounted for a large share of fiscal receipts. ${ }^{6}$

Security concerns and the desire to narrow the gap with the West put a high premium on investment and the expansion in China's producer goods' sector, e.g., steel, machine tools and chemicals. As in the USSR, and in sharp contrast to the first three decades of the $20^{\text {th }}$ century, Chinese planning pursued industrial development without reference to comparative advantage. Moreover, with the notable exception of the sizable inflows of equipment, technology and expertise from the Soviet bloc during the 1950s, Chinese leaders limited the country's ties to global markets. International isolation, which reflected a combination of ideological conviction and the impact of a US-led trade embargo, pushed China's trade ratio far below the levels attained during the 1930s (Table 3).

\subsection{Achievements}

These institutional arrangements delivered three decades of rapid industrial expansion surpassing earlier rates of growth. After doubling between 1949 and 1952 with the revival of the economy, industrial output grew more than 11 per cent per annum between 1952 and 1978 (Table 1), while employment grew nearly ten-fold, from 5.3 million in 1952 to 53.3 million in 1978 (Table 2).

In line with planners' objectives, quantitative expansion brought a pronounced shift in the structure of industry, which moved away from formerly dominant consumer manufactures toward intermediate and producer products. Entirely new industries appeared - for example manufacture of trucks, tractors, radios, telecom and power generating equipment. The rise of machinery, from only 6.2 per cent of industrial output in 1952 to 25.7 per cent in 1978 (Table 7), highlights the direction and magnitude of structural change. By the 1970s, the sectoral composition of industry resembled that of a country with significantly higher GDP per capita, e.g. Japan in the late 1950s.

Declining spatial concentration, a trend already visible between 1933 and 1952, continued in the socialist plan environment (Table 7). China's First Five-Year Plan (19531957) concentrated investment in inland provinces, bypassing coastal regions that had dominated pre-war manufacturing. Planners also relocated personnel and factories

\footnotetext{
${ }^{6}$ Hsiao (1987, p. 12) gives annual fiscal "receipts from enterprises" (including, but not limited to industrial firms); this category accounted for over 50 per cent of budgetary revenue in 14 of 16 years between 1959 and 1974.
} 
from militarily vulnerable coastal cities to interior regions. Dispersion continued during the 1960s under the "Third Front" program, which situated industrial facilities in remote interior locations to guard against potential U.S. or Soviet attacks (Naughton, 1988). With these shifts, the Herfindahl index for provincial industrial output continued the decline begun during the 1930s, falling from 0.09 in 1952 to 0.06 in 1978 (Table 4).

Beyond the cities, and largely outside the formal plan, development of rural industry represents an unusual feature of Chinese industrialization. Rural enterprises, most run by agricultural collectives, aimed to serve agriculture and to use local resources to satisfy local demand for cement, fertilizer, machinery, electricity and coal. Promotion of rural industry began in the mid-1950s, experienced explosive but hugely wasteful growth during the Great Leap Forward (1958-1960), and re-emerged in the late 1960s following major post-Leap retrenchment. By 1978, rural industry (including mining and construction as well as manufacturing) employed 19.7 million workers (Thirty Years, 2008 , p. 248). Rural industry was particularly successful in the suburbs of major coastal cities that had also developed the largest non-agricultural sectors prior to 1949 , i.e. the regions disfavoured by both the early PRC investment plans and then by the $3^{\text {rd }}$ Front policy.

By the 1970s, Chinese manufacturing, no longer limited to the production of low-end, labour-intensive consumer products, spanned virtually the entire range of industrial activity, including sophisticated operations involving petroleum refining, nuclear weapons and earth satellites. Despite its brief duration, the flow of aid and trade from the USSR and its East European allies provided an unprecedented cross-national technology transfer that accelerated China's effort to broaden the span of domestic manufacturing. ${ }^{7}$ Beyond the growth of output and extension of the product mix, socialist planning brought a vast expansion of industrial capabilities. The accumulation of production experience and the spread of mass education multiplied the stock of factory-level technical capabilities and human capital. In addition, the plan system underwrote a massive expansion of institutions, resources and personnel for high-level technical training and research efforts. Ministries and major SOEs established networks of universities, technical schools and R\&D facilities. By the late 1970s, there were over 700 R\&D institutes with over 500,000 scientists and engineers, nearly as many as in the United States (Gu, 1999, pp. 56-58; Nolting and Feshbach, 1981, p. 44).

\footnotetext{
${ }^{7}$ During the 1950s, imports are constituted nearly twenty per cent of newly added producer durables (Field 1980, p. 233).
} 


\subsection{Shortcomings}

Despite important advances, the achievements of Chinese industry during the plan era fell far short of potential. The most obvious indicator is slow productivity growth (World Bank, 1985, p. 110; Chen et al., 1988) despite a long list of favourable circumstances: unprecedented official promotion of industrial development, large inflows of Soviet technology and capital goods, huge increases in public expenditure on R\&D, and rapid expansion of primary education and basic health care.

Rising capital per worker - the consequence of steep increases in investment spending, much of it directed toward industry ${ }^{8}$ - coincided with surprisingly slow growth of industrial output per worker - with several sectors, including metallurgy, suffering declines in labour productivity between 1965 and 1978 (Field, 1982). Factoring in improvements in human capital suggests negative TFP growth (Zhu, 2012). This "disappointing" outcome meant that "rapid expansion of output came almost entirely from massive growth of labour and especially capital inputs" (Chen et al., 1988, pp. 585587). The obvious implication is that the beneficial impact of multiple sources of productivity growth was overwhelmed by institutional blockages and policy failures. ${ }^{9}$ With a rising share of GDP directed to investment to offset declining TFP, consumption languished.

Chinese observers were quick to highlight the institutional sources of poor outcomes. A 1982 editorial explained that "the basic causes of low [industrial] labour productivity" included poor morale, bureaucratism and lax discipline "in many factories" (Field, 1982, p. 656). Shigeru Ishikawa (1983, p. 275) highlighted shortcomings in the "investment goods sub-sector," the core of the planned economy, which, despite receiving "an extremely high proportion of investment funds. . . . [and] scarce foreign currency," delivered weak results. "The marginal output-capital ratio . . . decreased considerably over time and hence the expected rise in the growth rate of national income [and other important results were] ... not realized".

\footnotetext{
${ }^{8}$ The share of gross capital formation in aggregate expenditure, which Rawski (1989, pp. 260-261) places at 10.3 per cent during 1931-1936 (excluding inventory accumulation), is estimated at 22.2, 25.4, 28.4 and 38.2 per cent for 1952, 1957, 1965 and 1978 respectively. Industry's share of basic construction, the largest component of investment spending, was 31.3 per cent in 1953, 43.9 per cent in 1956, and at least 50 per cent throughout 1957-1978 with the exception of 1965, when the figure was 49.1 per cent (GDP, 2007, p. 19; Investment, 1987, p. 97).

${ }^{9}$ Lardy (1983) makes a similar point regarding agriculture.
} 
Rawski (1975) and others replicated previous work on Soviet industry which showed how material-balance planning and ambitious physical output targets led managers to pursue quantity at the expense of quality, variety, innovation, cost, and customer satisfaction; to systematically overstate input requirements and understate production capacity; and to hoard materials, labour and backup production facilities. Naughton (1995, pp. 49-50) found that the accumulation of inventories and unfinished construction in China was considerably worse than in the USSR.

Specific Chinese policies added further impediments. Of particular importance in this connection was enforced self-sufficiency at the national, regional and even local level, which limited both international and domestic trade and moved investment priorities far away from comparative advantage. Suspicion of intellectuals and technical expertise, which periodically stripped firms, government offices, schools and research institutions of scarce and valuable talent, also came with high costs.

\section{Chinese Industry during the Reform Era, 1978-2008}

Beginning in the late 1970s, a succession of reform initiatives gradually led to a hybrid that combines important elements of planning, state ownership and official direction with a revival of the open, private, market-based system of the 1920s and 1930s. This novel arrangement has extended the rapid growth attained under the former plan system, but combined quantitative expansion with market liberalization, deep integration with global markets, and rapid upgrading that has enabled a growing array of Chinese manufacturers to approach global frontiers of technical sophistication and product quality.

We separate the reform era into two periods, with 1995 as the break point.

\subsection{Early reforms, $1978-1995$}

China's initial reforms included selective opening to the global economy, most notably through the establishment of Special Economic Zones (SEZs) that welcomed foreign investment and allowed duty-free import of materials used to manufacture export goods, as well as incremental reform of state-owned enterprises. The critical element in early-stage reform, however, was market liberalization, which advanced along multiple axes.

Price and quantity determination, formerly the near-exclusive preserve of official plan bodies, moved toward market outcomes. Separate initiatives empowering firms to arrange the disposition of above-quota output and establishing "dual pricing," i.e. 
market pricing of non-plan exchanges, injected scarcity-based marginal values into a formerly rigid pricing system (Naughton, 1995). By 1991, "market forces" surpassed "state order" in determining prices of "production materials"; in 1995, the share of market forces reached 77.9 per cent (Rawski, 2000, p. 320).

Introduction of partial profit retention (for firms) and bonuses (for workers) reversed the plan system's destruction of incentives and weakened the corrosive impact of soft budget constraints among state-owned firms.

Reforms began to dismantle plan-era restrictions that had limited the mobility of people, goods, technology, funds and information across China's internal and international boundaries. These initiatives sparked what developed into vast flows of migrant labour to coastal industrial centres; they also undermined protectionist policies aimed at retaining local materials and blocking inflows of manufactures.

Finally, early reforms reduced impediments to entry and exit in a growing array of industries. Although SOE monopoly persisted in some sectors (Haggard and Huang, 2008), others opened up for entry by non-state actors - urban collectives, rural township and village enterprises (TVEs), private domestic ventures and foreign-invested firms.

\subsection{Outcomes to 1995}

Notwithstanding the continuation of plan allocations and prices, the revival of incentives, domestic trade and market-determined prices allowed producers some scope to modify their product mix, choose among alternate suppliers or extend sales efforts into new markets without cumbersome bureaucratic approvals. New entrants, operating outside the plan system, could occupy market niches overlooked by the plan apparatus. Growing availability of materials and services outside the plan encouraged specialization, reversing the excessive vertical integration developed in the plan environment.

At the same time, growing openness steadily enlarged the global impact on China's formerly isolated and largely self-reliant industrial sector, which faced the prospect of accessing a backlog of overseas innovations dating back to the 1930s. Manufactured exports rose over 100-fold in U.S. dollar terms between 1978 and 1995 (Table 3). Imports were heavily weighted with capital equipment, raw materials and, reflecting China's growing participation in global supply chains, industrial components, most delivered to the factory sector.

FDI increased dramatically (Tables 5 and 10). Firms with Hong Kong and Taiwan ties, run by entrepreneurs with long experience in producing and exporting consumer products, were especially prominent, constituting the majority of enterprises in the SEZs. 
Specializing in the assembly and export of textiles, apparel, footwear and electronics, these firms became the leading source of China's exports. Nonetheless, the share of foreign-linked firms in industrial output (Table 5), the share of exports in sales of manufactured goods (Table 3 ), and the share of FDI in overall investment (Fixed Assets, 2002, p. 20) remained below 15 per cent throughout this period.

However, tariff and non-tariff barriers, remnants of the industrial plan system, ad hoc disruption of (especially private) business, and inadequate infrastructure (frequent power shortages, overcrowded railways, poor roads, primitive telecommunications) limited the economy's response to these opportunities, just as similar domestic constraints had restricted the responsiveness of private actors during the decades prior to 1937.

Industrial growth during the early reform years was somewhat higher than in 1965-1978 (Table 1), with big increases in the growth of textiles and food processing (Table 9). Although the share of machinery, chemicals and metallurgy changed little between 1978 and 1995 (Table 7), industry shifted toward the same coastal provinces that had led the development of private-sector manufacturing prior to World War II (Table 4) and, reflecting the tripling of China's trade ratio from 11.8 to 38.7 per cent between 1978 and 1995 (Table 3), toward sectors and products in which China held a comparative advantage.

Growth occurred primarily outside the state sector, reducing the SOE output share from 80 to 49 per cent between 1978 and 1995 (Industry, 1985, pp. 31-32; Table 5). TVEs emerged as a key source of fresh momentum. Concentrated in the once again dynamic coastal regions, these firms, largely owned and managed by township and village governments (although some were in reality private), absorbed labour released by the productivity growth that accompanied agricultural reform (Lin, 1992) and tapped expanding domestic trade networks to sell their products and obtain equipment, materials and expertise. Powerful incentives, limited technical expertise and hard budget constraints (Whiting, 2001) led TVEs to focus on labour-intensive consumer products. Flexible, ambitious, and aligned with China's comparative advantage, TVEs quickly entered international markets, accounting for 16.3 per cent of aggregate exports in 1990 and 28.9 per cent in 1995 (Thirty Years, 2008, p. 326; Yearbook, 2014, p. 329).

As waves of new entrants slashed returns in the consumer sector, China's leaders began to rethink the position of the state sector. Sectors like garments and beverages were designated as "competitive industries" - meaning that market competition could determine the fate of SOEs in those product lines. Planning increasingly focused on a limited array of "strategic" sectors seen as deserving special attention and support. 
Despite the reforms, state firms in the secondary sector (industry and construction) absorbed over half (and often much more) of aggregate investment outlays in every year between 1981 and $1995 .{ }^{10}$ SOEs enjoyed priority access to bank lending. Licensing of advanced technology and joint ventures with overseas multinationals - for example Beijing Jeep and Shanghai-Volkswagen - provided additional support for the expansion of SOE technical capabilities and competitiveness. Despite these advantages, SOEs lagged behind other firms in both financial returns (Holz, 2003, pp. 165-170) and productivity growth (Jefferson et al., 2000, pp. 797-804). This motivated efforts beginning in the mid-1990s to expand the reform effort.

\subsubsection{Reforms since 1995}

On the domestic front, the government privatized (largely to insiders) or shut down large numbers of small, inessential or poorly-performing SOEs: more than 75,000 SOE firms disappeared, and, with them, the jobs of 15-20 million workers. The state sector's share of industrial output from 48.6 to 24 per cent between 1995 and 2008 (Table 5). The remaining SOEs were larger and increasingly concentrated in sectors like steel, precision machinery and chemicals that the state identified as strategic or "pillar" industries.

A series of policy initiatives sought to make the SOEs more commercial and more innovative. A State-Owned Assets Supervision and Administration Commission (SASAC) was established to consolidate management of the state's ownership interests and take the lead in restructuring major SOEs to boost their competitiveness (Naughton, 2015). The government poured resources into the promotion of "indigenous innovation" that would establish China as a producer (rather than, as in the past, a purchaser) of cuttingedge technology. The state also pushed Chinese firms, with SOEs again in the forefront, to "go outward" by increasing overseas direct investment (Table 10) in order to deepen market experience and accelerate both the absorption and the development of advanced technologies.

Legal reforms that explicitly affirmed the legitimacy of private enterprise encouraged the rapid expansion of privately owned manufacturing, involving both new enterprise formation and privatization of TVEs and urban collectives. Restrictions on the movement of people and goods were further eroded.

On the external front, multiple initiatives - falling tariffs and non-tariff barriers, fresh measures to encourage FDI, allowing large numbers of firms to engage in international trade, and more generous currency retention rights for exporters - culminated in

\footnotetext{
${ }^{10}$ See authors' file Investment-by-sector-ownership, compiled from official statistical publications.
} 
China's 2001 accession to the World Trade Organization (Lardy, 2002; Branstetter and Lardy, 2008). Reform leaders like Zhu Rongji saw a strong link between external and internal reforms. They viewed China's WTO agreements as a "credible commitment" to the continued pursuit of market outcomes to which domestic players, especially major SOEs, would be compelled to adjust. From this perspective, the domestic impact of external reforms may have exceeded the direct benefits of WTO entry.

\subsubsection{Outcomes since 1995}

Industrial growth accelerated during this period (Table 1). The output share of textiles and food processing continued to decline, while machinery's share rose to almost half (Table 7). ${ }^{11}$ The southeast coast continued to advance, raising its output share to 45.8 per cent by 2008 (Table 4).

While manufactured exports grew rapidly, China's rapidly expanding, highly competitive, and increasingly demanding domestic market absorbed over 80 per cent of incremental manufacturing output during both sub-periods of the reform era (Table 3). For most manufacturers, the opportunity to sell into this domestic market, the world's largest for products ranging from autos to cell phones and nuclear power equipment, provided the biggest boost to growth. Although market opening has allowed foreign-linked firms to gain ground in a number of sectors, domestic enterprises have achieved strong competitive positions, in some cases - beer, home appliances, heavy construction equipment - recapturing market share initially ceded to foreign operators. As of 2008 , domestic firms accounted for over threefourths of industrial output (Table 5 ). ${ }^{12}$

The reforms increased the incentives for firms to invest in capability building, as well as their ability to upgrade. Incremental innovation and upgrading allowed firms to narrow the productivity gap vis à vis domestic and international leaders, similar to recent developments elsewhere in Asia as well as China's longer-term catch-up dating from the late $19^{\text {th }}$ century. FDI, which accelerated following Deng Xiaoping's southern trip (1992) and continued at high levels thereafter, was a major contributor (Table 10). A significant portion of the FDI originated from

\footnotetext{
11 The extraordinarily high share of machinery in GVIO in 2008 may in part reflect inaccurately recorded relative price trends.

12 PRC statistics classify the entire output of firms with any offshore (including Hong Kong, Taiwan and Macao) ownership, no matter how small, as "foreign." The practice of "round-tripping," in which domestic funds are moved offshore and then repatriated to take advantage of regulatory provisions favouring foreign capital, leads official data to overstate output from foreign-linked firms by an undetermined, but probably declining amount.
} 
relatively small firms based in Hong Kong and Taiwan. Large multinationals like Boeing, General Electric, Hitachi and Volkswagen also established substantial Chinese operations.

Foreign firms initially focused on using Chinese land and labour to reduce production costs for components and final goods sold overseas. "Processing" exports, an arrangement that allows duty-free importation of materials and components, propelled Chinese engagement with global production chains. As foreign firms gained familiarity with the rising capabilities of Chinese manufacturers, they turned to domestic suppliers to source an increasing range of components and help lower costs. This multiplied the dispersion of international standards and advanced business practices (inventory management, production scheduling, quality control etc.) among domestic manufacturers, as the supply chain of a single assembly plant for vehicles or electrical equipment can involve thousands of component and material vendors. Finally, in anticipation of rapidly rising incomes and a growing middle class, FDI was increasingly directed toward serving the growing domestic market, a shift that intensified competition in many domestic product categories.

The experience of Chinese firms in telecoms and construction equipment illustrates the contribution of openness and liberalization to industrial upgrading. Huawei, initially dismissed as technically weak by both Chinese planners and their MNE partners, followed the path of China's pre-war "match king" by building expertise in neglected markets - first in small cities in China's interior and then in Africa - to develop innovative products that subsequently penetrated high-end markets both within and outside China (Brandt and Thun, 2013). Reflecting spillovers from China's growing R\&D expenditures (Hu and Jefferson, 2008), research engineers designed inexpensive concrete pumps that allowed Sany, an obscure Hunan start-up, to develop into an internationally competitive manufacture of construction equipment (Brandt and Thun, 2015).

Growing market penetration and rising unit values confirm the growing sophistication and rapid upward migration of Chinese manufactured exports along international price/quality ladders (Schott, 2008; Mandel, 2013). The domestic (Chinese) content of exports has increased significantly, reflecting a deepening of local supply chains and capabilities (Kee and Tang, 2015). Manufacturing productivity growth, largely coming from the entry of new firms, now parallels the achievements of other successful economies during periods of similarly rapid industrial expansion (Brandt, Van Biesebroeck and Zhang, 2012). The most dynamic outcomes are in sectors that are highly contested, readily accessible to foreign investors, and obstruct neither entry nor exit by domestic firms (Brandt, Rawski and Sutton, 2008; Brandt and Thun, 2015; Brandt et. al, 2012, revised 2016).

At the same time, there is large-scale inefficiency within individual sectors: Hsieh and Klenow (2009) conclude that reducing efficiency gaps between firms within sectors to levels observed 
in U.S. manufacturing could have raised productivity in China's factories by 30-50 per cent during 1998-2005. Preferential access to capital, energy and other key inputs are the likely culprits for these costs, which often show up in the form of excess capacity in firms and sectors. Table 11 reveal big differences in productivity dynamics between sectors with 1998 SOE output shares above or below 50 per cent. For sectors in which SOEs contributed the majority of 1998 output, outcomes are uniformly weak: continuing firms contribute negatively to productivity growth, as do new entrants, including new private firms - meaning that new firms enter with productivity levels below those of incumbents. For sectors with 1998 SOE shares below 50 per cent, the picture is the opposite, with productivity rising, primarily because entering firms deliver above-average results, thus boosting sector-wide outcomes.

Our survey ends with a profound contradiction. As China navigates the fourth decade of a transition that produced results beyond anyone's wildest dreams, the strategy of placing stateowned firms at the core of the nation's development plans, a constant feature of economic policy-making dating from the Chiang Kai-shek administration of the 1930s, emerges yet again as an obstacle to achievement of ambitious economic goals. With the current administration seemingly committed to the traditional policy of populating the economy's commanding heights with state enterprises, we must ask whether the economy's forward momentum will be sufficient to carry the costs associated with state ownership.

\subsection{Conclusion}

Since its inception during the second half of the $19^{\text {th }}$ century, modern industry has amassed an enviable record of rapid growth. Only World War II halted the long-term expansion of output, and even then on-going capacity growth pushed output to unprecedented levels once hostilities came to an end.

China's initial forays into manufacturing clustered around Shanghai and the southeastern coastal provinces, regions that subsequently maintained their leading position even as modern industry spread across China's cities and even penetrated into the countryside. $19^{\text {th }}$-century industrialization combined official ventures oriented toward defence-related sectors and private efforts focused on mechanized processing of farm products. Following several decades of mainly private initiatives oriented toward labour-intensive consumer manufactures, Japan's annexation of Manchuria in 1931 prompted a shift toward military-linked producer products and public ownership that continues to occupy a major plank of Chinese economic strategy.

Industrial expansion has involved qualitative change along with growing output volume. The initially narrow range of domestic manufactured goods has expanded dramatically. Chinese firms now populate every industrial segment. In a growing array of sectors, leading Chinese manufacturers can compete with leading multinationals. In sector after sector - yarn, machine 
tools, power generating equipment, computers - the transition of Chinese goods from laggards to formidable rivals follows a common path. Imports of novel products establish a market that domestic firms seek to penetrate. Their efforts, initially based on imitation, result in the production of cheap, low-quality domestic substitutes. Some of these producers of inferior goods mobilize sufficient capabilities to upgrade their products, thus beginning the ascent of that particular sector's price-quality ladder.

Crucial for growth, capability accumulation and upgrading are openness to international flows of goods, capital, people, technology and ideas; domestic market liberalization; and supportive institutions. We see these as mutually reinforcing, although Chinese reality defies simple analysis, and there may be substitutes for these essential ingredients (for example, personal networks extending into the ranks of government and Communist Party officials may partially offset the absence of secure property rights in today's PRC). The 1910s and 1920s saw substantial growth with minimal official support. Between 1949 and 1978, the PRC's planned economy delivered both rapid growth and considerable expansion of capabilities with limited openness and no domestic liberalization. And the current reform era has produced an astonishing burst of growth and upgrading in the face of massive institutional deficits and considerably less openness or liberalization than existed in the early $20^{\text {th }}$ century.

The objective of "enriching the nation and strengthening the army" motivated official behaviour throughout our period, though the capacity of the state to underwrite militarily significant industrial efforts expanded hugely under the PRC. The shift from market dominance toward state control, conventionally attributed to the inception of Soviet-type planning during the 1950s, actually began much earlier. Chiang Kai-shek's Nanjing government begins to embrace planning and state ownership from 1931; in the northeast, Japanese influence propelled a similar shift as early as the late 1910s. The question of the benefits and costs of state ownership, management and control has thus permeated Chinese policy discussions during the past 80 years, and remains central today.

Looking ahead, we can anticipate continued deepening of industrial capabilities through multiple channels: domestic and overseas education, accumulation of production and marketing experience, increasing domestic R\&D outlays, learning from large-scale inward and outbound FDI, and energetic, well-funded promotion of officially mandated nodes of "indigenous innovation." At the same time, immense industrial advance coexists with staggering inefficiency, an outcome that extends across multiple institutional settings extensive planning with near-total public ownership prior to 1978, the initial reform period of the 1980s and early 1990s, and the more open and further liberalized system of the last two decades. 
This essay resonates with a larger body of work that highlights state-owned industry as the chief contributor to the vast inefficiencies that litter China's development path. It is not simply that SOEs, led by Communist party appointees who must juggle (often conflicting) commercial and political objectives, have recorded consistently weak cost, profit and productivity performance. We now have ample evidence that state ownership slows overall growth and impinges on financial stability and structural change.

China's leaders are well aware of these costs, and presumably understand that on-going efforts to attack corruption, encourage strong firms to absorb weak rivals, and exhort participants to follow official priorities cannot succeed where past reforms have failed. However, the value to Chinese elites of a large and growing state sector, which provides a treasure house of patronage and rents as well as an army of powerful and responsive subordinates, banishes serious consideration of sweeping SOE privatization from the current policy agenda.

Will China's on-going momentum continue to override the current system's immense costs, maintaining something approaching the rapid progress of the past several decades? Might SOE giants slow the pace of innovation by blocking or absorbing potential rivals? Will SOE service oligopolies escalate system costs as the integration of telecoms and other services with manufacturing advances? Only time will tell. 


\section{References}

Bian, M.L. 2002. The Sino-Japanese War and the Formation of the State Enterprise System in China: A case study of the Dadukou Iron and Steel Works, 1938-1945. Enterprise and Society 3, 80-123.

Brandt, L. 1985. Chinese Agriculture and the International Economy, 1870-1930: A Reassessment. Explorations in Economic History, 22, 168-93.

Brandt, L. 1989. Commercialization and Agricultural Development: Central and Eastern China, 1870-1937. Cambridge; New York: Cambridge University Press.

Brandt, L., Ma, D. and Rawski, T. 2014. From Divergence to Convergence: Reexamining the History behind China's Economic Boom. Journal of Economic Literature 52, 45-123.

Brandt, L., Rawski, T. and Sutton, J. 2008. China's Industrial Development. In China's Great Economic Transformation (Eds, Brandt, L. and Rawski, T.). Cambridge and New York: Cambridge University Press, 569-632.

Brandt, L. and Thun, E. 2010. The Fight for the Middle: Competition and Upgrading in Chinese Industry. World Development, 38, 1555-1574.

Brandt, L. and Thun, E. 2013. Going Mobile in China: Shifting Value Chains and Upgrading in the Mobile Telecom Sector. International Journal of Technological Learning, Innovation and Development, 4, 148-180.

Brandt, L. and Thun, E. 2015. Constructing a Ladder for Growth: Policy, Markets and Industrial Upgrading in China. World Development, 80, 78-95.

Brandt, L., Van Biesebroeck, J. and Zhang, Y.F. 2012. Creative Accounting or Creative Destruction? Firm-Level Productivity Growth in Chinese Manufacturing. Journal of Development Economics 97, 339-351.

Brandt, L., Van Biesebroek, J. L, Wang, L.H. and Zhang, Y.F. 2012, revised 2016. WTO Accession and Performance of Chinese Manufacturing Firms. CEPR Discussion Paper No. 9166.

Branstetter, L. and Lardy, N.R. 2008. China's Embrace of Globalization. In China's Great Economic Transformation (Eds, Brandt, L. and Rawski, T.). Cambridge and New York: Cambridge University Press, 633-682.

Brown, S.R. 1978. The Partially Opened Door: Limitations on Economic Change in China in the 1860s. Modern Asian Studies, 12, 177-192. 
Brown, S.R. 1979a. The Ewo Filature: A Study in the Transfer of Technology to China in the 19th Century. Technology and Culture, 20, 550-568.

Brown, S.R. 1979b. The Transfer of Technology to China in the Nineteenth Century: The Role of Direct Foreign Investment. The Journal of Economic History 39, 181-197.

Chan, W.K.K. 1977. Merchants, Mandarins, and Modern Enterprise in Late Ch'ing China. Cambridge, MA: Harvard University East Asian Research Center, distributed by Harvard University Press.

Chao, K. 1977. The Development of Cotton Textile Production in China. Cambridge, MA: Harvard University East Asian Research Center, distributed by Harvard University Press.

Chao, K. 1982. The Economic Development of Manchuria: The Rise of a Frontier Economy. Ann Arbor: Center for Chinese Studies, University of Michigan.

Chen, K. et al. 1988. Productivity Change in Chinese Industry: 1963-1985. Journal of Comparative Economics 12, 570-591.

Chen, N.R. 1967. Chinese Economic Statistics: A Handbook for Mainland China. Chicago, Aldine.

Cochran, S.G. 1992. Three Roads into Shanghai's Market: Japanese, Western, and Chinese Companies in the Match Trade, 1895-1937. In Shanghai Sojourners (Eds, Wakeman, F. and Yeh, W.H.). Berkeley: Institute of East Asian Studies, 35-75.

Cochran, S.G. 2000. Encountering Chinese Networks. Berkeley: University of California Press. Compendium. 2009. Xin Zhongguo liushiwunian tongji ziliao huibian [China Compendium of Statistics 1949-2008]. Beijing: Zhongguo tongji chubanshe.

Dinh, H.T. et al. 2013. Tales from the Development Frontier: How China and Other Countries Resolve the Binding Constraints in Light Manufacturing to Create Jobs and Prosperity. Washington DC: World Bank.

Esherick, J. 1972. Harvard on China: The Apologetics of Imperialism. Bulletin of Concerned Asian Scholars 4, 9-16.

Feuerwerker, A. 1970. Handicraft and Manufactured Cotton Textiles in China, 1871-1910. Journal of Economic History 30, 338-378.

Field, R.M. 1980. Real Capital Formation in the People's Republic of China, 1952-73. In Quantitative Measures of China's Economic Output (Ed, Eckstein, A). Ann Arbor: University of Michigan Press, 194-245. 
Field, R.M. 1982. Slow Growth of Labour Productivity in Chinese Industry, 1952-81. China Quarterly 96, 641-664.

Fixed Assets. 2002. Zhongguo guding zichan touzi tongji shudian (1950-2000) [Statistics on investment in fixed assets of China, 1950-2000]. Beijing: Zhongguo tongji chubanshe.

Gardella, R. 1994. Harvesting Mountains: Fujian and the China Tea Trade, 1757-1937. Berkeley: University of California Press.

GDP 2007. Zhongguo guonei shengchan zongzhi hesuan lishi ziliao 1952-2004 [Data of Gross Domestic Product of China, 1952-2004]. Beijing: Zhongguo tongji chubanshe.

Grove, L. 2006. A Chinese Economic Revolution: Rural Entrepreneurship in the Twentieth Century. Lanham: Rowman and Littlefield.

Gu, S.L. 1999. China's Industrial Technology: Market Reform and Organizational Change. London: Routledge.

Haggard, S. and Huang, Y.S. 2008. The Political Economy of Private Sector Development in China. In China's Great Economic Transformation (Eds, Brandt, L. and Rawski, T.). Cambridge and New York: Cambridge University Press, 337-374.

Holz, C.A. 2003. China's Industrial State-owned Enterprises: Between Profitability and Bankruptcy. New Jersey: World Scientific.

Hou, C.M. 1965. Foreign Investment and Economic Development in China, 1840-1937. Cambridge: Harvard University Press.

Hsiao, L.L. 1974. China's Foreign Trade Statistics, 1864-1949. Cambridge, MA: East Asian Research Center Harvard University, distributed by Harvard University Press.

Hsiao, K.H. (1987). The Government Budget and Fiscal Policy in Mainland China. Taipei: ChungHua Institution for Economic Research.

Hsieh, C.T. and Klenow, P. 2009. Misallocation and Manufacturing TFP in China and India. Quarterly Journal of Economics 124, 1403-1448.

Hu, A.G.Z. and Jefferson, G.H. 2008. Science and Technology in China. In China's Great Economic Transformation (Eds, Brandt, L. and Rawski, T.). Cambridge and New York: Cambridge University Press, 286-336.

Huang, P.C.C. 1985. The Peasant Economy and Social Change in North China. Stanford, Calif.: Stanford University Press. 
India Data-book. 2014. Data-book Compiled for use of Planning Commission. Posted at http://planningcommission.nic.in/data/datatable/data 2312/comp data2312.pdf

Industry. 1985. Zhongguo gongye jingji tongji ziliao 1949-1984 [Statistical materials on China's industrial economy, 1949-1984]. Beijing: Zhongguo tongji chubanshe.

Industry. 1989. Zhonghua renmin gongheguo 1985-nian gongye pucha ziliao jianyaoben [Overview of Materials from the PRC 1985 Industrial Census]. Beijing: Zhongguo tongji chubanshe.

Investment 1987. Zhongguo guding zichan touzi tongji ziliao 1950-1985 [Statistical materials on China's investment in fixed assets, 1950-1985]. Beijing: Zhongguo tongji chubanshe.

Ishikawa, S. 1983. China's Economic Growth since 1949 - An Assessment. The China Quarterly, 94, 242-281.

Jefferson, G.H. et al. 2000. Ownership, Productivity Change, and Financial Performance in Chinese Industry. Journal of Comparative Economics 28, 786-813.

Kee, H.L. and Tang, H.W. 2015. Domestic Value Added in Exports: Theory and Firm Evidence from China. American Economic Review, forthcoming.

Kirby, W. C. 1984. Germany and Republican China. Stanford: Stanford University Press.

Kirby, W. C. 1990. Continuity and Change in Modern China: Economic Planning on the Mainland and on Taiwan, 1943-1958. Australian Journal of Chinese Affairs 24, 121-141.

Köll, Elisabeth. 2003. From Cotton Mill to Business Empire: The Emergence of Regional Enterprises in Modern China. Cambridge MA: Harvard University Asia Center.

Kraus, R.A. 1980. Cotton and Cotton Goods in China, 1918-1936. New York \& London: Garland Publishing.

Lardy, N.R. 1983. Agriculture in China's Modern Economic Development. Cambridge and New York: Cambridge University Press.

Lardy, N.R. 2002. Integrating China into the Global Economy. Washington DC: Brookings Institution Press.

Li, P.F. et al. 2012. Network Dynamics and Cluster Evolution: Changing Trajectories of the Aluminium Extrusion Industry in Dali, China. Journal of Economic Geography 12, 127-155.

Lin, J.Y. 1992. Rural Reforms and Agricultural Growth in China. American Economic Review 82, 34-51. 
Liu, D.J. 1937. Zhongguo gongye diaocha baogao [Report of a survey of China's industries]. 3 vols. Shanghai: Jingji tongji yanjiusuo.

Liu, T.C. and Yeh, K.C. 1965. The Economy of the Chinese Mainland: National Income and Economic Development, 1933-1959. Princeton, N.J.: Princeton University Press.

Ma, D. 2008. Economic Growth in the Lower Yangzi Region of China in 1911-1937: A Quantitative and Historical Analysis. Journal of Economic History 68, 355-392.

Mandel, B. 2013. Chinese Exports and U.S. Import Prices. Staff Reports, Federal Reserve Bank of New York, No 591.

Mantetsu keizai chōsakai. 1933. Manshū keizai nempō 1933 [Manchuria Economic Yearbook, 1933]. Tokyo: Kaizōsha.

Maskin, E., Qian, Y.Y., and Xu, C.G. 2000. Incentives, Information, and Organizational Form. Review of Economic Studies 67, 359-378.

Minami, R. and Makino, F. (Eds). 2014. Ajia keizai chōki tōkei 3: Chūgoku [Long-term Asian historical statistics 3: China]. Tokyo: Toyokeizai shinposha.

Moulder, F.V. 1977. Japan, China and the Modern World Economy: Towards a Reinterpretation of East Asian Development ca. 1600-ca. 1918. Cambridge: Cambridge University Press.

Murphey, R. 1977. The Outsiders: The Western Experience in India and China. Ann Arbor: University of Michigan Press.

Nakamura, T. 1983. Economic Growth in Prewar Japan (Trans. Feldman, R.A.). New Haven: Yale University Press.

Naughton, B. 1988. The Third Front: Defence Industrialization in Chinese Interior. The China Quarterly 115, 351-386.

Naughton, B. 1995. Growing Out of the Plan: Chinese Economic Reform 1978-1993. Cambridge: Cambridge University Press.

Naughton, B. 2015. The Transformation of the State Sector: SASAC, the Market Economy, and the New National Champions. In State Capitalism, Institutional Adaptation, and the Chinese Miracle (Eds, Naughton, B. and Tsai, K.), 46-71.

Nolting, L.E. and Feshbach, M. 1981. Statistics on Research and Development Employment in the U.S.S.R. Washington DC: U.S. Dept. of Commerce, Bureau of the Census. 
Ohkawa, K. et al. 1974. Kokumin shotoku [National Income]. Tokyo: Toyo Keizai Shinposha.

Ohkawa, K. and Shinohara, M. 1979. Patterns of Japanese Economic Development: A Quantitative Appraisal. New Haven: Yale University Press.

Rawski, T.G. 1975. China's Industrial System. In China: A Reassessment of the Economy (United States Congress, Joint Economic Committee). Washington, D.C.: U.S. Government Printing Office, 175-198.

Rawski, T.G. 1980. China's Transition to Industrialism: Producer Goods and Economic Development in the Twentieth Century. Ann Arbor: University of Michigan Press.

Rawski, T.G. 1989. Economic Growth in Prewar China. Berkeley: University of California Press.

Rawski, T.G. 2000. China's Move to Market: How Far? What Next? In China's Future:

Constructive Partner or Emerging Threat? (Eds, Carpenter, T.G. and Dorn, J.A.). Washington DC: Cato Institute, 317-339.

Remer, C.F. 1933. Foreign Investments in China. New York: Macmillan.

Reynolds, B.L. 1974. Weft: The Technological Sanctuary of Chinese Handspun Yarn. Ch'ing-shih wen-t'i, 3, 1-19.

Schott, P. K. 2008. The Relative Sophistication of Chinese Exports. Economic Policy. 53, 5-49.

Statistics Japan. 2011. Japan Statistical Yearbook 2011. Accessed May 29, 2015 from http://www.stat.go.jp/english/data/nenkan/back61/index.htm

Statistics Japan. 2012. Historical Statistics of Japan. Accessed May 29, 2015 from http://www.stat.go.jp/english/data/chouki/

Sutton, J. 2012. Competing in Capabilities: The Globalization Process. Oxford: Oxford University Press.

Thirty Years. 2008. Zhongguo xiangzhen qiye 30 nian [30 years of China's township-village enterprises]. Beijing: Zhongguo nongye chubanshe.

U.S. Department of State. 1949. Energy Resources of the World. Washington: U.S. Government Printing Office.

Wang, Y.C. 1992. Secular Trends of Rice Prices in the Yangzi Delta, 1638-1935. In Chinese History in Economic Perspective (Eds. Rawski, T.G. and Li, L.M.). Berkeley: University of California Press, 35-68. 
Whiting, S.H. 2001. Power and Wealth in Rural China: the Political Economy of Institutional Change. Cambridge; New York: Cambridge University Press.

Wong, C. 1985. Material Allocation and Decentralization: Impact of the Local Sector on Industrial Reform. In The Political Economy of Reform in Post-Mao China (Eds, Perry, E.J. and Wong, C.). Cambridge, MA: Council on East Asian Studies/Harvard University, 253-278.

World Bank. 1985. China: Long-term Development Issues and Options. Baltimore: Johns Hopkins University Press.

Yamamoto, Y. 2003. Manshūkoku keizaishi kenkyū [Research on Manshūkoku economic history]. Nagoya: Nagoya daigaku shuppankai.

Yan, Z.P., et al. 1955. Zhongguo jindai jingjishi tongji ziliao xuanji. [Statistical materials on the Economic History of Modern China]. Beijing: Kexue chubanshe.

Yearbook. Annual. Zhongguo tongji nianjian [China Statistics Yearbook]. Beijing: Zhongguo tongji chubanshe.

Zeitz, P. 2013. Do Local Institutions Affect all Foreign Investors in the Same Way? Journal of Economic History 73, 117-141.

Zhang Y.F. [Chang Y.F.] 1989. "Qingmo Minchu de minying gongye" [Private sector industry during late Qing and under the early Republic]. Zhongyang yanjiuyuan jindaishi yanjiusuo jikan [Quarterly Journal of the Modern History Institute of the Academia Sinica] 18, 315-561.

Zhu, X.D. 2012. Understanding China's Growth: Past, Present, and Future. Journal of Economic Perspectives 26, 103-124. 


\section{Table 1. Comparative growth of industrial output, 1912-2008}

$\begin{array}{lcccc} & \text { China } & \text { Japan } & \text { India } & \text { USSR/Russia } \\ 1912-1936 & 8.0 & 6.7 & 3.4 & 4.8 \\ 1912-1949 & 4.1 & 2.5 & 3.9 & 3.9 \\ 1912-1952 & 6.2 & 4.0 & \text { N.A. } & 4.8 \\ 1952-1965 & 12.3 & 14.3 & 8.2 & 6.4 \\ 1965-1978 & 10.2 & 8.2 & 4.3 & 3.8 \\ 1978-1995 & 11.6 & 2.8 & 6.8 & \text { N.A. } \\ 1995-2008 & 13.8 & 0.7 & 7.8 & 3.1 \\ 1952-2008 & 11.9 & 6.1 & 6.8 & \text { N.A. } \\ 1912-2008 & 9.5 & 5.2 & 5.5 & \text { N.A. }\end{array}$

Sources: China: calculated from authors' file "Table 1 China Growth Rates 1912-

2008_7.10.15," available on request. Index for 1912-1949 from Minami and Makino (2014, annex table 4.D); link with 1952 from Liu and Yeh (1965, p. 66); index for 19522008 based on official data on industrial gross output; all output figures have been converted to 1980 prices. India: for $1911 / 12$ to $1999 / 2000$ - data compiled by S. Sivasubramonian, courtesy of Bishnupriya Gupta for manufacturing (excluding small industry), in constant 1946-47 prices; for 2000/01 and thereafter, GDP originating in manufacturing (at 2005 factor cost) from India Data-book (2014). Japan: linked index of production growth based on: for 1912-36: Ohkawa and Shinohara (1979, Tables A21A22); for 1936-1995: Statistics Japan (2012, Table 8-16); for 1995-2008: Statistics Japan (2011, Table 8-28). Russia:1912-1990 industrial output for the Russian Empire/USSR in constant 1913 rubles; 1991 and thereafter, industrial output for the Russian Federation, also in constant 1913 rubles. Data courtesy of Steven Nafziger. 
Table 2. Comparative industrialization: China, India, Japan and Russia/USSR, 19122008

\begin{tabular}{|c|c|c|c|c|c|c|c|}
\hline \multicolumn{8}{|c|}{$\begin{array}{l}\text { Cotton Yarn } \\
\text { Production (Mill. Lbs.) }\end{array}$} \\
\hline China & 221 & 990 & 1445 & 2860 & 5240 & 11928 & 38214 \\
\hline India & 647 & 1268 & 1452 & 2068 & 2006 & 3793 & 6774 \\
\hline Japan & 400 & 1261 & 635 & 1065 & 985 & 473 & 145 \\
\hline USSR/Russia & & 660 & & & 3580 & 436 & \\
\hline \multicolumn{8}{|c|}{$\begin{array}{l}\text { Electricity Production } \\
\text { (Bill kWh) }\end{array}$} \\
\hline China & 0.1 & 2.8 & 7.3 & 67.6 & 256.6 & 1007.0 & 3496.0 \\
\hline India & & 2.1 & 6.1 & 31.4 & 110.1 & 396.0 & 841.7 \\
\hline Japan & 1.1 & 19.5 & 52.0 & 179.6 & 564.0 & 990.0 & 1146.0 \\
\hline USSR/Russia & 2.0 & 16.4 & 119.1 & 506.7 & 1293.9 & 860.0 & 983.0 \\
\hline \multicolumn{8}{|c|}{$\begin{array}{l}\text { Ingot Steel Production } \\
\text { (Mill. Tonnes) }\end{array}$} \\
\hline China & 0.0 & 0.4 & 1.4 & 12.2 & 31.8 & 95.4 & 503.0 \\
\hline India & 0.0 & 0.5 & 1.6 & 6.4 & 9.9 & 22.0 & 57.8 \\
\hline Japan & 0.0 & 3.2 & 7.0 & 39.8 & 102.1 & 101.6 & 118.7 \\
\hline USSR/Russia & 4.2 & 8.9 & 34.5 & 91.0 & 151.5 & 51.6 & 68.5 \\
\hline \multicolumn{8}{|l|}{$\begin{array}{l}\text { Cement Production } \\
\text { (Mill. Tonnes) }\end{array}$} \\
\hline China & 0.1 & 0.8 & 2.9 & 16.3 & 65.2 & 475.6 & 1423.6 \\
\hline India & 0.0 & 1.1 & 4.6 & 10.6 & 19.4 & 74.0 & 177.0 \\
\hline Japan & 0.3 & 4.2 & 8.9 & 32.5 & 84.9 & 90.5 & 62.8 \\
\hline USSR/Russia & 1.6 & 2.7 & 13.9 & 72.4 & 127.0 & 36.4 & 53.6 \\
\hline \multicolumn{8}{|l|}{$\begin{array}{l}\text { Industrial } \\
\text { employment ( } \\
\text { Millions) }\end{array}$} \\
\hline China* & 0.7 & 1.1 & 5.3 & 16.6 & 53.3 & 147.4 & 126.3 \\
\hline India (formal only) & 0.9 & 1.5 & 3.2 & 4.7 & 5.4 & & 5.9 \\
\hline $\begin{array}{l}\text { India* (formal + } \\
\text { informal) }\end{array}$ & & & & & & 37.3 & 46.0 \\
\hline Japan & 1.6 & 4.2 & 7.2 & 11.5 & 13.3 & 14.6 & 8.3 \\
\hline USSR/Russia & 2.3 & $6.2-9.3$ & 16.8 & 27.4 & 29.0 & & \\
\hline
\end{tabular}

Sources: list of sources available from the authors. Note: USSR/Russia data for 1995 and 2008 are for the Russian Republic. * indicates employment data for manufacturing only. 
Table 3. Chinese exports of manufactures: Scale and share of production and overall exports, 1933-2008

\begin{tabular}{|c|c|c|c|c|c|c|c|}
\hline & Unit & 1933 & 1952 & 1965 & 1978 & 1995 & 2008 \\
\hline Total exports & RMB Bill. & $0.898^{*}$ & 2.71 & 6.31 & 16.76 & 1245.18 & 10039.49 \\
\hline of which: & & & & & & & \\
\hline Manufactures & RMB Bill. & $0.247^{*}$ & 0.41 & 2.84 & 9.22 & 1065.24 & 9492.50 \\
\hline $\begin{array}{l}\text { Share of Manufactures in } \\
\text { exports }\end{array}$ & percent & 27.5 & 15.0 & 45.0 & 55.0 & 85.5 & 94.6 \\
\hline GVIO, current prices & RMB Bill & & 34.9 & 140.2 & 423.7 & 9189.4 & 60737.92243 \\
\hline $\begin{array}{l}\text { Manufacturing Share in } \\
\text { GVIO }\end{array}$ & percent & 83.4 & 88 & 88 & 88 & 88 & 88 \\
\hline GVIO Manufacturing & RMB Bill & $2.645^{*}$ & 30.7 & 123.4 & 372.9 & 8086.7 & 53449.4 \\
\hline $\begin{array}{l}\text { Share of Manufacturing } \\
\text { output exported }\end{array}$ & percent & 9.3 & 1.3 & 2.3 & 2.5 & 13.2 & 17.8 \\
\hline Trade Ratio $[\mathrm{X}+\mathrm{M}] / \mathrm{GDP}$ & percent & 8.8 & 9.6 & 6.9 & 11.8 & 38.7 & 57.3 \\
\hline
\end{tabular}

Sources: Exports: for 1952-2008, Compendium (2009, 60); for 1933, authors' calculations combining Republic of China exports with separate Manshūkoku data from Yamamoto (2003). Exports of manufactures: authors' file "PRC Manufactured Exports," available on request. Manufacturing share in GVIO: authors' estimate based on file "Share of Mining and Utilities in GVIO 1933-2008," available on request.

Note: * 1933 data in billions of current pre-war yuan. 
Table 4. Share of industrial output by region, 1933-2008

$\begin{array}{lcccccc}\text { Region } & 1933 & 1952 & 1965 & 1978 & 1995 & 2008 \\ \text { NE } & 11.8 & 21.6 & 21.0 & 17.1 & 9.7 & 7.4 \\ \text { North } & 13.6 & 20.8 & 21.4 & 23.0 & 20.4 & 24.2 \\ \text { SE Coast } & 65.7 & 36.6 & 32.8 & 30.0 & 40.7 & 45.8 \\ \text { Central } & 7.9 & 11.0 & 12.3 & 15.0 & 16.0 & 12.9 \\ \text { NW } & 0.0 & 2.5 & 4.9 & 5.6 & 3.7 & 2.7 \\ \text { SW } & 0.9 & 7.5 & 7.6 & 9.3 & 9.6 & 7.0 \\ & & & & & & \\ \text { Total } & 100.0 & 100.0 & 100.0 & 100.0 & 100.0 & 100.0 \\ & & & & & & \\ \text { Herfindahl } & & & & & & \\ \text { Index } & 0.23 & 0.09 & 0.07 & 0.06 & 0.06 & 0.08\end{array}$

Regions:

$\begin{array}{lllllll}\text { NE } & \text { Heilongjiang } & \text { Jilin } & \begin{array}{l}\text { Liaoning } \\ \text { Inner }\end{array} \\ \text { North } & \text { Beijing } & \text { Tianjin } & \text { Mongolia } & \text { Shanxi } & \text { Hebei } & \text { Shandong } \\ \text { SE Coast } & \text { Jiangsu } & \text { Shanghai } & \text { Zhejiang } & \text { Fujian } & \text { Guangdong } & \text { Hainan } \\ \text { Central } & \text { Henan } & \text { Anhui } & \text { Hubei } & \text { Hunan } & \text { Jiangxi } & \\ \text { NW } & \text { Shaanxi } & \text { Ningxia } & \text { Gansu } & \text { Qinghai } & \text { Xinjiang } & \\ \text { SW } & \text { Sichuan } & \text { Chongqing } & \text { Guangxi } & \text { Yunnan } & \text { Guizhou } & \text { Xizang }\end{array}$

Sources: 1933: unpublished compilation by T. Kubo, Q. Guan and F. Makino based on Liu (1937). We incorporate figures for Guangzhou, Qingdao, Chahaer and Suiyuan into the provinces of Guangdong, Shandong, Hebei and Inner Mongolia respectively. We add data for 1933 factory output in Manchuria compiled by Liu and Yeh (1965, p.428), and partition the regional total among the three northeastern provinces in proportion to provincial electricity production in 1949 (Compendium 2009, 273, 307, 341). 1952-1978: compiled from official PRC publications. 1995 and 2008: compiled from individual firms' 1995 (industrial) and 2008 (economic) census records. 
Table 5. Breakdown of industrial output by ownership, 1933-2008 (per cent)

Foreign Firm Shares

Sector

Metallurgy

Power

Coal \& Coke

Petroleum

Chemicals

Machinery

Building

materials

Timber

Food \& Drink

Textiles

Paper

TOTAL

\begin{abstract}
1933
\end{abstract}

1985

$\begin{array}{cc}3.3 & 0.0 \\ 100.0 & 0.0 \\ 0.0 & 0.0 \\ 100.0 & 0.0 \\ 22.7 & 0.1 \\ 20.6 & 0.6 \\ & \\ 3.8 & 0.0 \\ 52.1 & 0.0 \\ 20.9 & 0.2 \\ 25.6 & 0.1 \\ 13.0 & 0.1 \\ & \\ 21.9 & 0.2\end{array}$

1995

2008

1933

Domestic Firm Shares

$\%$ of Domestic Non-State

$3.4 \quad 8.0$

96.7

1985

$1995 \quad 2008$

$1985 \quad 1995$

2008

$5.1 \quad 4.6$

$0.1 \quad 1.5$

$4.1 \quad 4.5$

$8.5 \quad 17.2$

100.0

100.0

100.0

$96.6 \quad 92.0$

100.0

94.9

99.9

95.9

91.5

100.0

77.3

79.4

99.4

84.3

95.4

98.5

95.5

$15.7 \quad 35.0$

82.8

65.0

$32.4 \quad 25.6$

$8.0 \quad 13.8$

$\begin{array}{ll}8.0 & 22.2\end{array}$

$\begin{array}{ll}5.5 & 3.7\end{array}$

$37.9 \quad 41.6$

$28.4 \quad 43.9$

96.2

100.0

95.1

92.8

$10.4 \quad 10.3$

47.9

100.0

99.8

99.9

74.4

$13.7 \quad 10.8$

99.9

89.6

94.3

86.3

94.2

89.7

82.1

89.2

84.7

99.8

90.2

76.7

78.1

$9.8 \quad 23.3$

(

\begin{abstract}
78.1
78.1
\end{abstract}

Sources: 1933: Liu and Yeh (1965), for China proper only (excluding Manchuria). Estimates for 1985 are from the industrial census summary volume Industry (1989). Estimates for 1995 and 2008 are based individual firms' records from the 1995 (industrial) and 2008 (economic) censuses. 
Table 6. Number of domestic, privately-owned modern factories established, by region and decade, 1841-1915

\begin{tabular}{|c|c|c|c|c|c|c|c|c|c|c|}
\hline Region & $1841-50$ & $1851-60$ & $1861-70$ & $1871-80$ & $\begin{array}{l}1881- \\
1890\end{array}$ & $\begin{array}{l}1891- \\
1900\end{array}$ & $\begin{array}{l}1901- \\
1910\end{array}$ & 1911-15 & $\begin{array}{c}\text { Pre-1911 } \\
\text { Total }\end{array}$ & $\begin{array}{l}\text { Pre-1911 } \\
\text { Share }\end{array}$ \\
\hline NE & & & & & 1 & 6 & 47 & 47 & 54 & 9.1 \\
\hline North & & & & 1 & 3 & 11 & 77 & 90 & 92 & 15.6 \\
\hline SE Coast & 1 & 4 & 3 & 3 & 37 & 69 & 203 & 209 & 320 & 54.1 \\
\hline Central & & & & 1 & & 11 & 66 & 38 & 78 & 13.2 \\
\hline NW & & & & & & & 1 & 5 & 1 & 0.2 \\
\hline sW & & & & & 1 & 2 & 43 & 49 & 46 & 7.8 \\
\hline Total & 1 & 4 & 3 & 5 & 42 & 99 & 437 & 438 & 591 & 100.0 \\
\hline
\end{tabular}

Source: authors' tabulation of materials in Zhang [Chang] (1989). 
Table 7. Breakdown of industrial output by sector

\begin{tabular}{|c|c|c|c|c|c|c|c|c|c|c|c|c|}
\hline Year & Coverage & Metallurgy & Power & $\begin{array}{c}\text { Coal and } \\
\text { Coke }\end{array}$ & Petroleum & Chemicals & Machinery & $\begin{array}{c}\text { Bldg } \\
\text { materials }\end{array}$ & Timber & $\begin{array}{l}\text { Food \& } \\
\text { Drink }\end{array}$ & Textiles & Paper \\
\hline \multirow[t]{2}{*}{1933} & Total & 1.9 & 0.9 & 4.4 & 0.5 & 1.4 & 5.2 & 1.8 & 5.4 & 30.9 & 42.4 & 5.0 \\
\hline & Only & 3.8 & 1.8 & 8.5 & 1.0 & 1.9 & 5.7 & 1.2 & 0.8 & 30.0 & 43.4 & 1.9 \\
\hline 1952 & Total & 5.4 & 1.4 & 4.6 & 0.6 & 1.9 & 6.2 & 2.8 & 9.2 & 31.4 & 34.5 & 2.2 \\
\hline 1965 & Total & 13.0 & 3.5 & 4.8 & 3.6 & 7.3 & 16.0 & 3.2 & 4.6 & 20.0 & 21.6 & 2.3 \\
\hline 1978 & Total & 10.3 & 4.1 & 3.8 & 6.8 & 12.1 & 25.7 & 4.2 & 2.4 & 12.9 & 16.3 & 1.5 \\
\hline 1995 & Total & 8.7 & 3.6 & 1.6 & 2.4 & 15.0 & 29.9 & 6.9 & 1.5 & 11.6 & 15.9 & 2.6 \\
\hline 2008 & Total & 8.1 & 3.5 & 0.8 & 0.8 & 12.7 & 49.1 & 4.1 & 1.4 & 7.4 & 10.0 & 2.0 \\
\hline
\end{tabular}

Sources: For 1933, authors' rearrangement of gross output data compiled in Liu and Yeh (1965) into 12-sector structure used for post-1949. We adjust their estimates of handicraft food and textile output to exclude non-commercial production for household own consumption. For 1952-2008, Chinese yearbook and census data.

Notes: All data have been converted into 1980 prices. This classification reflects 2-digit categories used in Chinese industrial data during the planned economy period. "Machinery" includes metal products; "Textiles" includes manufacture of garments and shoes. We omit a residual sector identified as "other" (qita) in the sources. 
Table 8. Gross output value and employment in manufacturing by type of firm, China

proper, 1933

\begin{tabular}{|c|c|c|c|c|c|c|c|c|}
\hline & & Gross Ou & put Value & & & Employn & ent & \\
\hline & $\begin{array}{l}\text { Chinese } \\
\text { Firms } \\
\text { Million }\end{array}$ & $\begin{array}{l}\text { Foreign } \\
\text { Firms } \\
\text { yuan }\end{array}$ & $\begin{array}{l}\text { Chinese } \\
\text { Firms } \\
\text { Share }\end{array}$ & $\begin{array}{c}\text { Foreign } \\
\text { Firms } \\
\text { Share }\end{array}$ & $\begin{array}{l}\text { Chinese } \\
\text { Firms } \\
\text { Thousands }\end{array}$ & $\begin{array}{l}\text { Foreign } \\
\text { Firms } \\
\text { Thousands }\end{array}$ & $\begin{array}{l}\text { Chinese } \\
\text { Firms } \\
\text { Share }\end{array}$ & $\begin{array}{c}\text { Foreign } \\
\text { Firms } \\
\text { Share }\end{array}$ \\
\hline $\begin{array}{l}\text { Metallurgy } \\
\text { Power }\end{array}$ & 83 & 2.8 & 96.7 & 3.3 & 20.1 & 0.9 & 95.7 & 4.3 \\
\hline $\begin{array}{l}\text { Coal \& Coke } \\
\text { Petroleum }\end{array}$ & 0.5 & & 100.0 & 0.0 & 0.2 & & 100.0 & 0.0 \\
\hline Chemicals & 86.7 & 25.5 & 77.3 & 22.7 & 42.3 & 8.9 & 82.6 & 17.4 \\
\hline $\begin{array}{l}\text { Machinery } \\
\text { Bldg }\end{array}$ & 68.8 & 17.9 & 79.4 & 20.6 & 52.2 & 8.2 & 86.4 & 13.6 \\
\hline materials & 45.8 & 1.8 & 96.2 & 3.8 & 36 & 1.1 & 97.0 & 3.0 \\
\hline Timber & 5.6 & 6.1 & 47.9 & 52.1 & 1.7 & 1.7 & 50.0 & 50.0 \\
\hline Food \& Drink & 597.8 & 158.1 & 79.1 & 20.9 & 72.8 & 28.3 & 72.0 & 28.0 \\
\hline Textiles & 793.6 & 272.7 & 74.4 & 25.6 & 505.6 & 108.3 & 82.4 & 17.6 \\
\hline Paper & 74.9 & 11.2 & 87.0 & 13.0 & 43.8 & 3.8 & 92.0 & 8.0 \\
\hline Other & 13.8 & 1.5 & 90.2 & 9.8 & 7.9 & 1.4 & 84.9 & 15.1 \\
\hline Total & 1770.5 & 497.6 & 78.1 & 21.9 & 782.6 & 162.6 & 82.8 & 17.2 \\
\hline
\end{tabular}

Source: Liu and Yeh (1965, 426-428). Totals may not sum due to rounding.

Note: This table excludes data for Manchuria, for which Liu and Yeh estimate 1933

output at 376.7 million yuan and 1933 factory employment at 129.5 thousand (ibid.). In Manchuria, the share of foreign (i.e. Japanese) firms in 1931 gross output value for manufacturing was 41.2 per cent (Mantetsu keizai chōsakai 1933, 568-569). If 41.2 per cent of Manchuria's 1933 manufacturing output came from foreign-owned firms, the share of foreign firms in total manufacturing output for that year would be 30.4 per cent. 
Table 9. Real annual growth rates for gross output value, 1952-2008 (per cent)

$\begin{array}{lcccc} & 1952-1965 & 1965-1978 & 1978-1995 & 1995-2008 \\ \text { Sector } & & & & \\ \text { Metallurgy } & 18.4 & 7.4 & 10.3 & 14.7 \\ \text { Power } & 18.8 & 10.7 & 10.5 & 15.0 \\ \text { Coal \& Coke } & 10.9 & 7.5 & 5.9 & 9.5 \\ \text { Petroleum } & 27.4 & 14.8 & 4.7 & 5.9 \\ \text { Chemicals } & 22.8 & 13.6 & 12.7 & 13.9 \\ \text { Machinery } & 19.0 & 13.4 & 12.3 & 19.8 \\ \text { Bldg materials } & 11.9 & 11.6 & 14.7 & 10.7 \\ \text { Timber } & 4.9 & 3.9 & 8.5 & 14.8 \\ \text { Food \& Drink } & 6.8 & 5.7 & 10.7 & 11.4 \\ \text { Textiles } & 6.7 & 7.0 & 11.2 & 11.3 \\ \text { Paper } & 10.8 & 5.8 & 15.2 & 13.1 \\ & & & & \\ \text { TOTAL } & 12.3 & 10.2 & 11.6 & 13.8\end{array}$

Sources: Table 1 and data underlying Table 7. 


\section{Table 10. Inward and outward FDI (US\$ billion)}

$\begin{array}{lccc}\text { Year } & 1990 & 2000 & 2010 \\ \text { FDI Inflow } & \mathbf{3 . 4 8} & \mathbf{4 0 . 7 1} & \mathbf{1 0 5 . 7} \\ & & & \\ \text { FDI Sources } & & & \\ \text { Asia } & & 25.48 & \\ \quad \text { Hong Kong } & 1.91 & 15.5 & 60.6 \\ \quad \text { Japan } & 0.5 & 2.92 & 0.71 \\ \quad \text { Korea } & & 1.49 & 2.7 \\ & & & \\ \text { Europe } & & 4.76 & \\ \quad \text { Germany } & 0.02 & 1.04 & 0.89 \\ \quad \text { UK } & 0.01 & 1.16 & 0.71 \\ \quad & & \\ \text { North America } & & 4.78 & \\ \quad \text { US } & 0.46 & 4.38 & 3.02 \\ \quad \text { Canada } & 0.41 & 0.28 & 0.71 \\ \quad \text { FDI Outlfow } & \mathbf{0 . 8 3} & \mathbf{0 . 9 2} & \mathbf{6 8 . 8 1}\end{array}$

Source: Yearbook, 1991, 2001, 2011. 
Table 11. Sectoral SOE shares and TFP growth, 1998-2007

\begin{tabular}{lccccc} 
& Total & \multicolumn{3}{c}{ Sources of Change in TFP } \\
& $\begin{array}{c}\text { Change } \\
\text { in In TFP }\end{array}$ & Within & Between & Entry & Exit \\
Sectors & -0.117 & -0.048 & 0.007 & -0.080 & 0.004 \\
SOE Share $>0.50$ & 0.208 & 0.050 & -0.024 & 0.175 & 0.007 \\
Soe Share $<0.50$ & 0.107 & 0.019 & -0.014 & 0.096 & 0.006 \\
All Sectors & & & & &
\end{tabular}

Source: calculations based on firm-level data.

Notes:

1. Changes in TFP are based on estimates for a gross output function. TFP growth on a value added basis can be obtained by multiplying these estimates by $1 / \mathrm{V}$, where $V$ is value-added as a percentage of gross output. A value added ratio of 0.25 implies TFP growth on a value added basis that is 4 times higher than on a gross output basis.

2. Sector shares for SOEs are based on data for 1998.

3. "Within" represents the growth in productivity amongst firms operating in both 1998 and 2007; "between" is the growth in TFP coming from the reallocation of resources to more productive firms; "entry" is from new firms not in the sample in 1998 but present in 2007, and "exit" is from firms operating in 1998, but no longer operating by 2007. 